\title{
Pupil-sparing Isolated Fascicular Third Cranial Nerve Palsy due to Infarction: Report of a Case and Literature Review
}

\author{
Min-Ju Kang ${ }^{1}$, Dong-Jin Shin ${ }^{1}$, Kwang-Dong Choi ${ }^{2}$, Ji-Soo Kim ${ }^{3}$ and Dong Hoon Shin ${ }^{1 *}$ \\ ${ }^{1}$ Department of Neurology, Gachon University Gil Medical Center, Incheon, South Korea \\ ${ }^{2}$ Department of Neurology, Pusan National University Hospital, Busan, South Korea \\ ${ }^{3}$ Department of Neurology, Seoul National University College of Medicine, Seoul National University Bundang Hospital, Seoul, South Korea
}

*Corresponding author: Dong Hoon Shin, Department of Neurology, Gachon University Gil Medical Center, Incheon, South Korea, Tel: +82-32-460-3346; Fax: +83-32-460-3344; E-mail: dr.donghoon.shin@gmail.com

Rec date: Oct 08, 2016, Acc date: Oct 14, 2016, Pub date: Oct 16, 2016

Copyright: (c) 2016 Kang MJ, et al. This is an open-access article distributed under the terms of the Creative Commons Attribution License, which permits unrestricted use, distribution, and reproduction in any medium, provided the original author and source are credited.

\begin{abstract}
Because of their anatomic proximity, pupillary and inferior rectus functions are linked in most cases of fascicular oculomotor palsy, with either sparing or involvement of both. A 40-year-old woman presented with painless binocular diplopia and left ptosis. Examination additionally showed limitations of the adduction and depression in the presence of normal supraduction and intact pupillary function in the left eye.

Findings of other neurological neuro-ophthalmologic examination were normal. A magnetic resonance imaging revealed a diffusion restriction in the left dorsomedial midbrain. An ischemic lesion restricted to the oculomotor fascicles can cause inferior rectus palsy in the presence of pupillary sparing, which should be differentiated from a microvasculopathic lesion involving the subarachnoid portion of the oculomotor nerve.
\end{abstract}

Keywords: Midbrain; Cerebral infarct; Oculomotor fascicle; Diplopia; ptosis; Unilateral

\section{Introduction}

Pupil-sparing isolated third cranial nerve palsy mostly indicates a microvascular lesion involving the subarachnoid portion of the oculomotor nerve. Even though isolated fascular third cranial palsy is extremely rare, it was once suggested that pupillary and inferior rectus functions may be linked, with sparing or involvement of both, in most cases of fascicular oculomotor palsy since the nerve fibers for the inferior rectus and pupil sphincter are located nearby in the oculomotor fascicles [1-4].

Herein, we present a patient with unilateral ptosis, and medial and inferior rectus palsy without a pupillary involvement from a midbrain infarction. We also performed a systematic literature review of the cases on isolated fascicular third nerve palsy to confirm that coinvolvements or co-sparing of the inferior rectus and pupillary function is the rule in lesions involving the oculomotor fascicle.

\section{Case Report}

A 40-year-old woman presented sudden binocular diplopia and left ptosis for two days. She also reported mild headache and nausea with the ocular symptoms. She had a history of an anterior chamber paracentesis for central retinal artery occlusion in the left eye two years before. Findings of general physical examination were normal. The patient showed an incomplete left ptosis and limitations of adduction and depression. However, the supraduction, abduction and pupillary function were preserved (Figure 1a).

Findings of other neurologic examination were normal. The electrolytes, renal function, and complete blood counts were also within normal ranges. However, the activity of protein $\mathrm{S}$ was measured $38 \%$ (normal range: $55 \%$ to $123 \%$ ). Magnetic resonance imaging (MRI) showed a focal diffusion restriction involving the left dorsomedial portion of lower midbrain. No vascular abnormalities or other parenchymal lesions were found (Figure 1b). She was diagnosed with pupil sparing isolated fascicular third cranial nerve palsy from an acute midbrain infarction due to protein $S$ deficiency. The ptosis and adduction limitation began to improve two days later, and resolved by two weeks.

\section{Literature Review}

We conducted a review of the literature on clinical features of fascicular third cranial nerve palsy due to ischemia. This was performed by a web-based search for English (www.ncbi.nlm.nih.gov/ pubmed) publications using the following terms: oculomotor nerve; third cranial nerve; stroke; ischemia; ischemic; infarct; infarction; fascicle; fascicular palsy; midbrain; mesencephalon; intra-axial. Our search was conducted up to June, 2016. In addition, we reviewed the reference list of the articles identified by this search strategy. We excluded the cases with an etiology other than infarction (such as hemorrhage, demyelinating, inflammation, infection, and compression by mass), oculomotor nuclear involvement, or other cranial nerve palsy. Patients without original data or a confirmation with MRI were also excluded.

We recruited 52 articles, and 24 of which were excluded due to absence of description on ocular motor findings $(n=3)$, lack of MR imaging $(n=2)$, other etiologies than ischemia $(n=4)$, language other than English $(\mathrm{n}=12)$, and associated ophthalmologic abnormalities such as oscillopsia and horizontal gaze palsy $(n=3)$. After a full-text review, we identified 46 cases of oculomotor fascicular palsy due to 
Citation: Kang MJ, Shin DJ, Choi KD, Kim JS, Shin DH (2016) Pupil-sparing Isolated Fascicular Third Cranial Nerve Palsy due to Infarction: Report of a Case and Literature Review . J Neurol Disord 4: 307. doi:10.4172/2329-6895.1000307

Page 2 of 4

midbrain infarct [5-33]. The demographics and clinical characteristics of these cases are shown in Table 1.

\begin{tabular}{|c|c|c|c|c|c|}
\hline \multicolumn{2}{|c|}{ Author } & Age/Gender & Signs & Pupil involve & Prevalence (\%) \\
\hline \multicolumn{3}{|c|}{ Both IR and pupillary involvement } & & & 15.2 \\
\hline 1 & Bogousslavsky J. et al. [5] & $71 / F$ & IR, MR, IO, SR, LP & yes & \\
\hline 2 & Bogousslavsky J. et al. [5] & $63 / F$ & IR, MR, IO, SR, LP & yes & \\
\hline 3 & Saeki $\mathrm{N}$ et al. [6] & $67 / \mathrm{M}$ & IR, MR, IO, SR, LP & yes & \\
\hline 4 & Leys D et al. [7] & $43 / \mathrm{M}$ & IR, MR, IO, SR & yes & \\
\hline 5 & Ogawa K et al. [8] & $75 / F$ & IR, MR, LP & yes & \\
\hline 6 & Ogawa K et al. [8] & $51 / \mathrm{M}$ & IR, MR, LP & yes & \\
\hline 7 & Randhawa S et al. [9] & $48 / \mathrm{M}$ & IR, MR, IO, SR, LP & yes & \\
\hline \multicolumn{4}{|c|}{ Pupillary involvement with sparing of IR } & & 17.4 \\
\hline 8 & Castro O et al. [10] & $69 / \mathrm{M}$ & 10 & yes & \\
\hline 9 & Murakami M et al. [11] & $62 / \mathrm{M}$ & MR, LP & yes & \\
\hline 10 & Tsuda $\mathrm{H}$ et al. [12] & $30 / \mathrm{M}$ & $\mathrm{MR}, \mathrm{IO}, \mathrm{SR}$ & yes & \\
\hline 11 & Ogawa K et al. [13] & $40 / F$ & MR & yes & \\
\hline 12 & Ogawa K et al. [13] & $30 / \mathrm{M}$ & $\mathrm{MR}, \mathrm{SR}$ & yes & \\
\hline 13 & Celebisoy $\mathrm{N}$ et al. [14] & $62 / \mathrm{M}$ & IO, SR, LP & yes & \\
\hline 14 & Chen L et al. [15] & $38 / \mathrm{M}$ & LP & yes & \\
\hline 15 & Hashimoto M et al. [16] & $55 / \mathrm{M}$ & none & yes & \\
\hline \multicolumn{3}{|c|}{ IR involvement with sparing of pupil } & & & 26.1 \\
\hline 16 & Ogawa K et al. [13] & $55 / / \mathrm{M}$ & $\mathrm{IR}, \mathrm{MR}, \mathrm{SR}$ & no & \\
\hline 17 & Champion BL et al. [17] & $24 / F$ & IR, MR, IO, SR, LP & no & \\
\hline 18 & Breen LA et al. [18] & $78 / F$ & IR, MR, IO, SR, LP & no & \\
\hline 19 & Lee DK et al [19] & $56 / F$ & IR & no & \\
\hline 20 & Saeki $\mathrm{N}$ et al. [6] & $68 / F$ & IR, MR, IO, SR, LP & no & \\
\hline 21 & Tsuda H et al. [20] & $72 / \mathrm{M}$ & IR, MR, SR, IO, LP & no & \\
\hline 22 & Kim JS et al. [21] & $53 / \mathrm{M}$ & IR, MR, IO, SR, LP & no & \\
\hline 23 & Kim JS et al. [21] & $42 / F$ & IR & no & \\
\hline 24 & Negoro K et al. [22] & $73 / F$ & IR & no & \\
\hline 25 & Ogawa K et al. [13] & $70 / \mathrm{M}$ & IR, MR, SR, LP & no & \\
\hline 26 & Ogawa K et al. [8] & $61 / \mathrm{M}$ & $\mathrm{IR}, \mathrm{MR}, \mathrm{SR}$ & no & \\
\hline 27 & Tsuda $\mathrm{H}$ et al. [23] & $80 / \mathrm{M}$ & IR, MR, IO, SR, LP & no & \\
\hline \multicolumn{3}{|c|}{ Sparing of both IR and pupil } & & & 41.3 \\
\hline 28 & Schwartz TH. et al [24] & $34 / F$ & LP, MR, IO, SR & no & \\
\hline 29 & Purvin V [25] & $72 / \mathrm{M}$ & MR, IO, SR, LP & no & \\
\hline 30 & Saeki N et al. [26] & $52 / \mathrm{M}$ & MR, IO, SR & no & \\
\hline
\end{tabular}


Citation: Kang MJ, Shin DJ, Choi KD, Kim JS, Shin DH (2016) Pupil-sparing Isolated Fascicular Third Cranial Nerve Palsy due to Infarction: Report of a Case and Literature Review . J Neurol Disord 4: 307. doi:10.4172/2329-6895.1000307

Page 3 of 4

\begin{tabular}{|c|c|c|c|c|}
\hline 31 & Rabadi MH et al. [27] & 79/M & MR, LP & no \\
\hline 32 & Miura $\mathrm{K}$ et al. [28] & 69/M & MR, IO, SR, LP & no \\
\hline 33 & Hriso E et al. [29] & $75 / F$ & IO, SR, LP & no \\
\hline 34 & Khurana DD et al. [30] & $68 / \mathrm{M}$ & MR, LP & no \\
\hline 35 & Tsuda H et al. [20] & 70/M & MR, IO, SR, LP & no \\
\hline 36 & Amano et al. [31] & $74 / M$ & MR, IO, SR, LP & no \\
\hline 37 & Amano et al. [31] & $66 / M$ & MR, IO, SR, LP & no \\
\hline 38 & Amano et al. [31] & 79/M & MR, IO, SR, LP & no \\
\hline 39 & Amano et al. [31] & $71 / \mathrm{M}$ & MR, IO, SR, LP & no \\
\hline 40 & Amano et al. [31] & $58 / \mathrm{M}$ & IO, SR, LP & no \\
\hline 41 & Fujioka T et al. [32] & $49 / \mathrm{M}$ & MR, IO, SR, LP & no \\
\hline 42 & Ogawa K et al. [13] & $88 / F$ & SR & no \\
\hline 43 & Ogawa K et al. [13] & $74 / F$ & MR, SR, LP & no \\
\hline 44 & Ogawa K et al. [8] & $78 / \mathrm{M}$ & MR, LP & no \\
\hline 45 & Choi YJ et al. [33] & $57 / F$ & IO, SR, LP & no \\
\hline 46 & Choi YJ et al. [33] & $71 / \mathrm{F}$ & IO, SR, LP & no \\
\hline
\end{tabular}

Table 1: Reported cases with isolated oculomotor fascicular infarction.

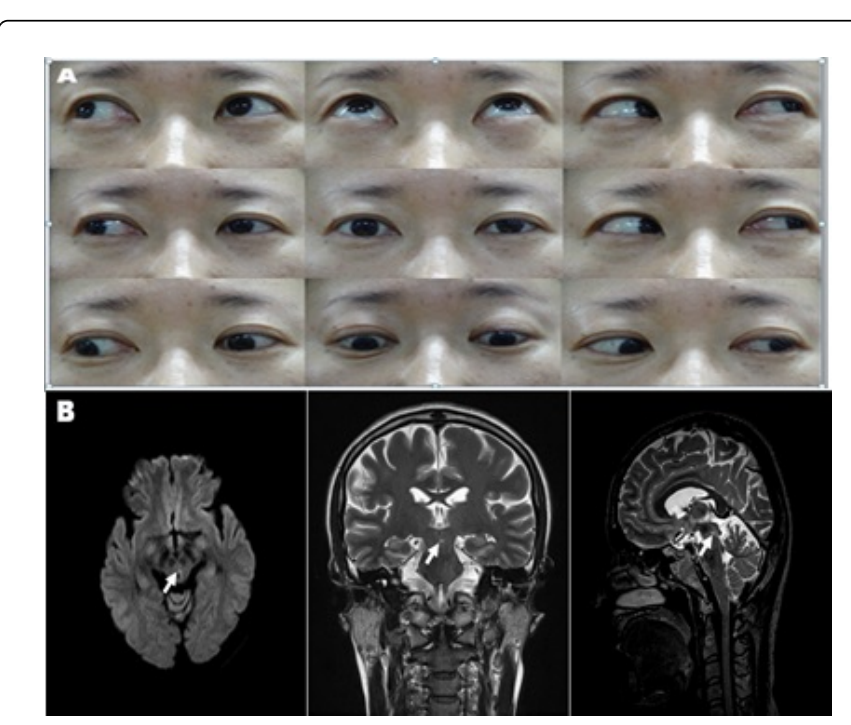

Figure 1: (a) Nine gaze photographs of the eyes show a ptosis and limitations of adduction and depression without a pupillary involvement in the left eye. (b) Diffusion- and T2-weighted images show a high signal lesion involving the left dorsomedial midbrain, consistent with an acute infarction involving the occulomotor fascicle.

\section{Discussion}

Our patient developed isolated fascicular third cranial nerve palsy due to an acute midbrain infarction. Of interest, the supraduction and pupillary function were spared in the presence of ptosis and limitations of adduction and infraduction.

The oculomotor fascicles are somatotopically arranged from lateral to medial [2] and rostrocaudally (Figure 2) $[3,4]$. Since the fascicles for the inferior rectus and pupillary sphincter are located adjacently in the rostral and medial part of the oculomotor fascicles [3,4], it was once suggested that the oculomotor fascicular infarctions may co-involve or co-spare the fibers for the pupillary sphincter and inferior rectus [1]. It was also presumed that preserved pupillary function in the presence of inferior rectus indicates an extra-axial oculomotor nerve palsy [1].

However, our patient with inferior rectus palsy and normal pupillary function from an infarction involving the oculomotor fascicle does not support this presumption (Figure 2). Furthermore, a thorough literature review revealed several cases of pupil-sparing inferior rectus palsy from ischemic lesions involving the oculomotor fascicle (Table 1). Indeed, the pupil was spared in $26.1 \%$ of patients with fascicular inferior rectus palsy and the inferior rectus was preserved in $17.4 \%$ of patients with an involvement of the pupillary fascicle.

Pupil-sparing isolated third cranial nerve palsy mostly indicates a microvascular lesion involving the subarachnoid portion of the oculomotor nerve. However, the pupillary function was spared in the majority of patients $(67.4 \%)$ with isolated oculomotor palsy from a fascicular infarction. 
Citation: Kang MJ, Shin DJ, Choi KD, Kim JS, Shin DH (2016) Pupil-sparing Isolated Fascicular Third Cranial Nerve Palsy due to Infarction: Report of a Case and Literature Review . J Neurol Disord 4: 307. doi:10.4172/2329-6895.1000307

Page 4 of 4

To the best of our knowledge, this is the first report on fascicular involvements of the inferior and medial recti and levator palpebrae in the presence of normal superior rectus function due to a midbrain infarction. Thus, fascicular lesions usually spare pupillary fibers and may involve fascicular subdivisions in various combinations. Even though rare, a fascicular lesion should also be considered in patients with isolated pupil-sparing third cranial nerve palsy.

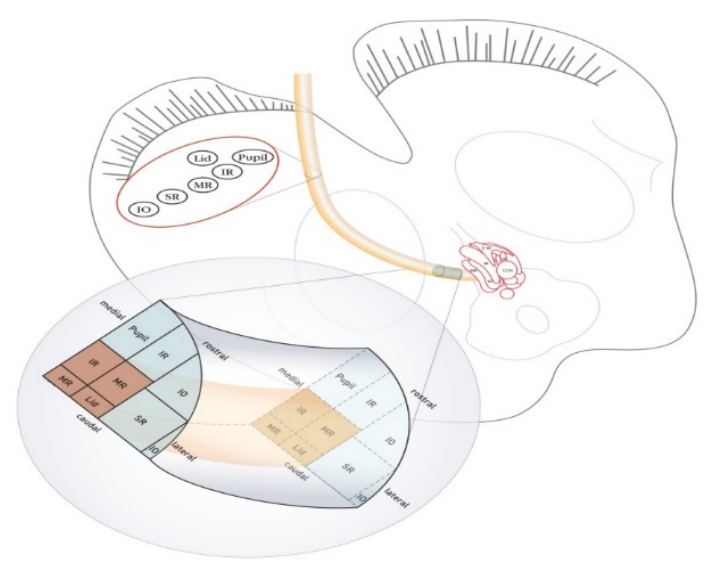

Figure 2: Schematic diagram of fascicular involvements in our patient. The shaded area depicts the possible extent of the lesion.

\section{References}

1. Johkura K (2009) Examination of eye movement. Shinkeinaika 70: 1-7.

2. Warwick R (1953) Representation of the extra-ocular muscles in the oculomotor nuclei of the monkey. J Comp Neurol 98: 449-503.

3. Ksiazek SM, Slamovits TL, Rosen CE, Burde RM, Parisi F (1994) Fascicular arrangement in partial oculomotor paresis. Am J Ophthalmol 118: 97-103.

4. Abdollah A, Francis G (1990) Intraaxial divisional oculomotor nerve paresis suggests intraaxial fascicular organization. Ann Neurol 28: 589-590.

5. Bogousslavsky J, Maeder P, Regli F, Meuli R (1994) Pure midbrain infarction clinical syndromes, MRI, and etiologic patterns. Neurology 44: 2032-2032.

6. Saeki N, Murai N, Sunami K (1996) Midbrain tegmental lesions affecting or sparing the pupillary fibres. J Neurol Neurosurg Psychiatry 61: 401-402.

7. Leys D, Nègre A, Rondepierre P, Ares G, Godefroy O (1992) Small infarct limited to the ventromedial part of the red nucleus: partial, transient and isolated unilateral oculomotor nerve palsy. Cerebrovasc Dis 2: 378-379.

8. Ogawa K, Suzuki Y, Takahashi K, Kamei S, Ishikawa H (2016) Clinical study of eleven patients with midbrain infarction-induced oculomotor nerve palsy. J Stroke Cerebrovasc Dis 25(7): 1631-1638.

9. Randhawa S, Donohue MM, Hamilton SR (2010) Concomitant presentation of three rare mesencephalic syndromes: Case report. Clin Neurol Neurosurg 112: 697-700.

10. Castro O, Johnson LN, Mamourian AC (1990) Isolated inferior oblique paresis from brain-stem infarction: perspective on oculomotor fascicular organization in the ventral midbrain tegmentum. Arch Neurol 47: 235-237.

11. Murakami M, Kitano I, Hitoshi Y, Ushio Y (1994) Isolated oculomotor nerve palsy following midbrain infarction. Clin Neurol Neurosurg 96: 188-190.
12. Tsuda H, Ishikawa H, Majima T, Sawada U, Mizutani T (2005) Isolated oculomotor nerve palsy in Churg-Strauss syndrome. Intern Med 44: $638-640$

13. Ogawa K, Suzuki Y, Oishi M, Kamei S (2011) Clinical study of twenty-one patients with pure midbrain infarction. Eur Neurol 67: 81-89.

14. Çelebisoy N, Çelebisoy M, Tokuçoğlu F, Özdemir I (2006) Superior division paresis of the oculomotor nerve: Report of four cases. Eur Neurol 56: 50-53.

15. Chen L, Maclaurin W, Gerraty R (2009) Isolated unilateral ptosis and mydriasis from ventral midbrain infarction. J Neurol 256: 1164-1165.

16. Hashimoto M, Ohtsuka K (1998) Bilateral internal ophthalmoplegia as a feature of oculomotor fascicular syndrome disclosed by magnetic resonance imaging. Am J Ophthalmol 125: 121-123.

17. Champion BL, Choy F, Schrieber L, Roche J, Rowe DB (2002) Isolated fascicular oculomotor nerve palsy as the initial presentation of the antiphospholipid syndrome. J Clin Neurosci 9: 691-694.

18. Breen LA, Hopf HC, Farris BK, Gutmann L (1991) Pupil-sparing oculomotor nerve palsy due to midbrain infarction. Arch Neurol 48 105-106.

19. Lee DK, Kim JS (2006) Isolated inferior rectus palsy due to midbrain infarction detected by diffusion-weighted MRI. Neurology 66: 1956-1957.

20. Tsuda H, Tanaka K (2012) Clinico-anatomical analysis of the fibers to the inferior rectus muscle in the oculomotor fascicles. Intern Med 51: 2031-2034.

21. Kim JS, Kang JK, Lee SA, Lee MC (1993) Isolated or predominant ocular motor nerve palsy as a manifestation of brain stem stroke. Stroke 24 581-586.

22. Negoro K, Sasabe F, Morimatsu M (1993) Isolated inferior rectus muscle paresis from midbrain infarction. Rinsho Shinkeigaku 33: 434-436.

23. Tsuda H, Fujita T, Maruyama K, Ishihara M (2015) Claude's syndrome without ptosis caused by a midbrain infarction. Intern Med 54: 1799-1801.

24. Schwartz TH, Lycette CA, Yoon SS, Kargman DE (1995) Clinicoradiographic evidence for oculomotor fascicular anatomy. J. Neurol. Neurosurg. Psychiatry 59: 338.

25. Purvin V (2010) Isolated fascicular third nerve palsy. J Neuroophthalmol 30: 263-265.

26. Saeki N, Murai H, Mine S, Yamaura A (2000) Fascicular arrangement within the oculomotor nerve MRI analysis of a midbrain infarct. J. Clin. Neurosci 7: 268-270.

27. Rabadi MH, Beltmann MA (2005) Midbrain infarction presenting isolated medial rectus nuclear palsy. Am J Med 118: 836-837.

28. Miura K, Nagaoka T, Ikeda K, Hirayama T, Kawabe K, et al. (2012) A case of inferolateral oculomotor fascicular infarction: a review of the clinicoradiological literature. Intern Med 51: 921-924.

29. Hriso E, Masdeu JC, Miller A (1991) Monocular elevation weakness and ptosis: An oculomotor fascicular syndrome? J Neuroophthalmol 11: 111-113.

30. Khurana DD (2011) Teaching neuroimages: A case of partial oculomotor palsy. Neurology 77: e150.

31. Amano Y, Kudo Y, Kikyo H, Imazeki R, Yamamoto M, et al. (2015) Isolated unilateral oculomotor paresis in pure midbrain stroke. J Neurol Sci 351: 191-195.

32. Fujioka T, Segawa F, Ogawa K, Kurihara T, Kinoshita M (1995) Ischemic and hemorrhagic brain stem lesions mimicking diabetic ophthalmoplegia. Clin Neurol Neurosurg 97: 167-171.

33. Choi YJ, Lee SH, Park MS, Kim BC, Kim MK (2015) Midbrain infarction presenting with monocular elevation palsy and ptosis: topographic lesion analysis. J Neuroophthalmol 35: 175-178. 